\title{
Factors Affecting Nurses' Patient Safety Culture and Job Satisfaction: A Comparative Study
}

\author{
Hemșirelerin Hasta Güvenliği Kültürünü ve Iș Doyumunu Etkileyen Faktörler: \\ Karșilaștırmalı Bir Çalıșma
}

\author{
Kader Ozturk', Arzu Karabag Aydin² \\ ${ }^{1}$ Department of Medical Services and Techniques, Ardahan University, Vocational School of Health Service, Ardahan, Turkey; \\ ${ }^{2}$ Department of Nursing, Faculty of Health Sciences, Kafkas University, Kars, Turkey
}

\begin{abstract}
Aim: This study was conducted to comparatively analyze factors affecting nurses' patient safety culture and job satisfaction.

Material and Method: This was a descriptive and cross-sectional study. The study sample comprised 260 nurses of two state hospitals and one university hospital in TRA2 in northeastern Turkey. Data were collected between August 2017 and March 2018. Data were collected using a Demographic Information Form, the Patient Safety Culture Scale and Job Satisfaction Scale in Nurses. ANOVA (F) and t test and the Mann-Whitney $U$ and Kruskal-Wallis $H$ tests were used for data analysis. Total scale score and subscale mean scores were also calculated. A correlation analysis was performed between nurses' patient safety culture and job satisfaction.

Results: The total Patient Safety Culture Scale and Job Satisfaction Scale mean scores were calculated respectively as $2.78 \pm 0.47$ and 3.34 \pm 0.68 . There was a statistically significant difference in Patient Safety Culture Scale and Job Satisfaction Scale scores between groups in terms of the independent variables "choosing the nursing profession of their own free will," "departmental position" and "skills-job match" ( $p<0.05)$. Also, a moderate and positive correlation was detected between nurses' job satisfaction and patient safety culture ( $p=0.000, r=0.598)$.

Conclusion: Thirty-one independent variables affecting nurses' patient safety and job satisfaction were identified. It was concluded that nurses who have a high patient safety culture have high job satisfaction.
\end{abstract}

Key words: job satisfaction; nursing; patient safety; quality of care
ÖZET

Amaç: Bu araștırma, hemșirelerde hasta güvenliği kültürünü ve iș doyumunu etkileyen faktörlerin karșılaștırmalı analizini yapmak amacıly gerçekleștirilmiștir.

Materyal ve Metot: Araștırma tanımlayıcı-kesitsel olarak yapılmıștır. Araștırmanın örneklemini Türkiye'nin Kuzeydoğusunda TRA2'de yer alan iki devlet hastanesinde ve bir üniversite hastanesinde çalıșan 260 hemșire olușturmuștur. Çalıșmanın verileri, Ağustos 2017 ile Mart 2018 tarihleri arasında toplanmıștır. Araștırma verileri "Tanıtıcı Özellikler Formu", "Hasta Güvenliği Kültürü Ölçeği” ve "Hemșirelerde iș Doyumu Ölçeği” kullanılarak elde edilmiștir. Veri analizinde parametrik testlerden Anova (F) ve t-Testi, non-parametrik testlerden Mann Whitney $U$ ve Kruskal Wallis $H$ testleri kullanılmıștır. Ayrıca ölçek toplam puan ve ölçek alt boyut puan ortalamaları hesaplanmıștır. Bunların yanı sıra "Hasta Güvenliği Kültürü" ile "Hemșirelerde iș Doyumu" arasındaki ilișkiye korelasyon analizi ile bakılmıștır.

Bulgular: Toplam puan ortalaması Hasta Güvenliği Kültürü

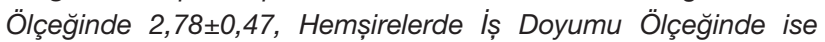

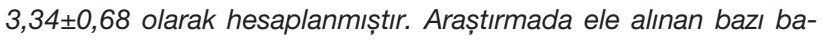
ğımsız değișkenlerden "hemșirelik mesleğini seçme durumuna", "çalıștığı bölümdeki pozisyonuna" ve "ișini yeteneklerine uygun bulma durumuna" göre Hasta Güvenliği Kültürü Ölçeği ve Hemșirelerde İs Doyumu Ölçeği her ikisinde de gruplar arasındaki fark istatistiksel olarak anlamlı bulunmuștur $(p<0,05)$. Ayrıca hasta güvenliği kültürü ile iș doyumu arasında pozitif yönlü bir ilișki saptanmiștır ( $p=0,000, r=0,598)$.

Sonuç: Hemșirelerde hem hasta güvenliği kültürünü hem de iș doyumunu 31 bağımsız değișkenin etkilediği saptanmıștır. Yüksek hasta güvenliği kültürüne sahip olan hemșirelerin iș doyumlarının da yüksek olduğu sonucuna ulașılmıștır.

Anahtar kelimeler: bakım kalitesi; hasta güvenliği; hemșirelik; iș doyumu

iletissim/Contact: Kader Öztürk, Ardahan University, Vocational School of Health Service, Medical Services and Techniques Department, 75000 Ardahan, Turkey • Tel:05362934980 • E-mail:kadercifci@ardahan.edu.tr • Geliș/Received:28.04.2021 • Kabul/Accepted:06.11.2021

ORCID: Kader Öztürk, 0000-0003-0424-0143 • Arzu Karabă̆ Aydın, 0000-0002-0002-4091 


\section{Introduction}

Despite recent technological advances and an increase in the number of treatment and care facilities and of scientific studies, patient safety remains a major problem in the healthcare system" ${ }^{1}$ The report titled "To Err is Human: Building a Safer Health System" released by the U. S. Institute of Medicine (IOM) in 1999 defines patient safety as "the prevention of harm to patients"2. According to the World Health Organization (WHO), one in ten patients in Europe is exposed to an avoidable injury or an adverse event in hospitals ${ }^{1}$. Annually, 421 million people receive inpatient care and approximately 42.7 million adverse events occur. Recent research shows that patient harm due to hospital care is the fourteenth cause of mortality and morbidity in the world ${ }^{3}$. Baker et al. ${ }^{4}$ reported that $7.5 \%$ of adverse events occur in hospitals in Canada and that $37 \%$ of them is preventable. Not only does this cause a variety of problems for patients and their families and for healthcare professionals, it is also a serious economic burden on the health system ${ }^{1}$. Patient safety, therefore, remains to be an issue that should be addressed by both organizations and the community ${ }^{5}$. According to the document that was most recently revised in 2012 by the International Council of Nurses, patient safety is the key element in the provision of high-quality healthcare and nursing care ${ }^{6}$. Such issues as cost-effectiveness and quality care, early discharge and the care burden for patients with acute and chronic diseases are becoming more and more important in all healthcare systems worldwide. The increasing changes and expectations in healthcare delivery affect quality of care, nurses' job satisfaction and patients' perceptions of care $^{7}$. Some of the environmental/organizational factors affecting job satisfaction in the existing literature are job quality, salary, staff safety, developmental and promotional opportunities, working conditions, management style, reward systems and relationships in the work environment ${ }^{8-10}$. Higher job satisfaction in nurses results in higher morale, higher institutional and occupational commitment, safe and higher quality of care and motivates nurses to continue to remain in the nursing profes$\operatorname{sion}^{11}$. Nurses' job satisfaction is an essential factor for nursing care institutes, which affects not only nursing quality but also patient satisfaction ${ }^{12}$.

\section{Aim}

This study aimed to determine the factors affecting nurses' patient safety culture and job satisfaction and the correlation between the two.
The study sought answers to the following questions:

What are the independent variables that affect nurses' patient safety culture?

What are the independent variables that affect nurses' job satisfaction?

Is there a correlation between nurses' patient safety culture and job satisfaction?

\section{Methods}

\section{Study Design}

This was a descriptive and cross-sectional study.

\section{Study Setting and Sample}

The study population comprised 425 nurses from two state hospitals and one university hospital in TRA2 (Ağrl, Kars, Ardahan, Iğdır) in northeastern Turkey. This study applied no specific sampling method. Nurses who volunteered to participate in the study were included in the sample. Of the nurses, 317 were contacted and informed about the purpose and procedure of the study prior to participation. Of these, 44 nurses did not agree to participate, and 13 nurses failed to complete the data collection form. Therefore, the final study sample consisted of 260 (61.2\%) nurses.

$n=\frac{N t^{2} p q}{d^{2}(N-1)+t^{2} p q} \frac{425 \times(1,96)^{2} \times 0.5 \times 0.5}{(0,05)^{2} \times 424+(1,96)^{2} \times 0.5 \times 0.5}=202$

\section{Data Collection Tools}

Data were collected using three forms: 1) Demographic Information Form (DIF); 2) Patient Safety Culture Scale (PSCS); and 3) Job Satisfaction Scale in Nurses (JSSN).

\section{Demographic Information Form (DIF)}

The original form of the DIF consisted of 26 openended questions eliciting information on institution, age, gender, marital status, educational degree, unit of service, skills-job match, institutional quality works and receiving training on quality.

\section{Patient Safety Culture Scale (PSCS)}

The PSCS was developed and its validity and reliability was established by Türkmen et al. ${ }^{13}$. It is a four-point Likert-type scale consisting of 51 items. It has five subscales: 1) management and leadership; 
2) employee behavior; 3) unexpected events and error reporting; 4) employee training; and 5) care environment. The mean scores of the total scale and its subscales are calculated for assessment. A mean score of $\leq 2$ indicates negative patient safety culture while a mean score of $\geq 2$ indicates positive patient safety culture. The reliability coefficient (Cronbach's alpha) of the PSCS was found to be $0.97^{13}$.

\section{Job Satisfaction Scale in Nurses (JSSN)}

The JSSN was developed by Muya et al in Japan in 2014. It was adapted to the Turkish language, and its validity and reliability were established by Yilmaz and Yildirim $^{14}$. It is a five-point Likert-type scale consisting of 27 items and four subscales: 1) positive emotions toward work; 2) appropriate support from superiors; 3) perceived significance in the workplace; and 4) pleasant working environment. The mean scores of the 27 items and the subscales are calculated for assessment. The closer the score is to five, the higher the job satisfaction. The Cronbach's alpha coefficient of the scale was determined to be $0.94^{14}$.

\section{Data Collection}

The data were collected between August 1, 2017 and March 9, 2018. Data collection sessions were scheduled at the participants' convenience. Head nurses were informed prior to data collection. Participants were asked to complete the data collection form in the presence of the researcher. In the event that we could not contact a participant in order to collect the data, we were able to learn the work days and hours of these nurses off the shift list and scheduled appointments for data collection at their convenience. Day and time appointments were taken from the nurses who were not available at the time, and the data were collected.

\section{Data Analysis}

The gathered data were analyzed using the IBM Statistical Package for Social Sciences (SPSS) for Windows Version 20.0. DIF frequencies were calculated. The PSCS and JSSN total score and subscale scores were calculated for each participant. The KolmogorovSmirnov $(K S)$ test was used to determine whether the data met the assumptions for parametric tests. ANOVA $(F)$ and $t$ test $(t)$ were used for normally distributed data whereas the Kruskal-Wallis $H(K W)$ and Mann-Whitney $U(Z)$ tests were used for non-normally distributed data. Bivariate Spearman's correlation was used to determine the correlation between nurses' patient safety culture and job satisfaction. For the significance level of statistical tests, $p<0.05$ value is accepted.

\section{Ethical Considerations}

The study was approved by the Ethics Committee of the Faculty of Medicine of *** University (No: 80576354 050-99/89, Date: April 27,2017). Written permission was obtained from the hospital management as well. All articles of Helsinki Declaration Principles were complied with in the research.

Nurses who voluntarily participated were informed about the purpose and procedure of the study, and they declared verbal consent to participate. In addition, written permission was obtained from the authors of the PSCS and the JSSN in order to use them as data collection tools in this study.

\section{Results}

Table 1 shows the participants' mean PSCS and JSSN total score and subscale scores, respectively. In this study, the internal consistency coefficients (Cronbach's alpha) of the PSCS and JSSN were 0.95 and 0.91 , respectively. There was a moderate and positive correlation between the PSCS and JSSN scores ( $p=0.000, r=0.598)$.

Table 1. Participants' mean PSCS and JSSN total score and subscale

\begin{tabular}{lc}
\hline Scores & \\
\hline & $\mathrm{X}^{\dagger} \pm \mathrm{SD}^{\ddagger}($ min-max) \\
PSCS total score & $2.78 \pm 0.47(1.12-4)$ \\
Subscales & \\
Management and leadership & $2.77 \pm 0.54(1-4)$ \\
Employee behavior & $2.82 \pm 0.53(1-4)$ \\
Unexpected events and error reporting & $2.75 \pm 0.57(1-4)$ \\
Employee training & $2.82 \pm 0.60(1-4)$ \\
Care environment & $2.75 \pm 0.57(1-4)$ \\
& $X^{\dagger} \pm \mathrm{SD}$ (min-max) \\
JSSN total score & $3.34 \pm 0.68(1.30-5)$ \\
Subscales & \\
Positive emotions toward work & $3.46 \pm 0.73(1.5-5)$ \\
Appropriate support from superiors & $3.13 \pm 1.22(1-5)$ \\
Perceived significance in the workplace & $3.80 \pm 0.70(1.5-5)$ \\
Pleasant working environment & $2.67 \pm 0.97(1-5)$ \\
\hline
\end{tabular}

†SD; standard deviation; $\ddagger$; mean; PSCS; patient safety culture scale; JSSN; job satisfaction scale in nurses. 
Table 2 shows the participants' demographic and job-related characteristics, respectively. When the PSCS and JSSN scores for the subscales "spending enough time with family" and "personality type (Type A or Type B)" were compared, it was found that the difference between the groups was statistically significant $(p<0.05)$. When the PSCS and JSSN scores for the subscales "choosing to be a nurse," "departmental position," "skills-job match," "participation in decision-making in the workplace," "loving being a nurse," "considering quitting" and "re-choosing nursing" were compared, it was found that the difference between the groups was statistically significant $(p<0.05)$.

Table 3 shows the participants' satisfaction with some working conditions based on their PSCS and JSSN scores. When the participants' PSCS and JSSN scores for the subscales "working hours and shifts," "division of tasks," "workload," "work pace," "number of nurses," "number of physicians," "number of patients," "interpersonal relationships in the workplace," "the institution they work for," "the unit in which they work," "training programs provided for patient safety" and "income" were compared, it was found that the difference between the groups was statistically significant $(p<0.05)$.

The participants' responses to questions on patient safety and quality. When the PSCS and JSSN scores for the subscales "presence of a patient safety committee in the institution," "having received training on patient safety before," "receiving training on patient safety in the institution," "wishing to serve on the patient safety committee," "finding the patient safety committee necessary," "reading the announcements on patient and staff safety," "receiving training on teamwork," "participating in staff orientation," "knowing about total quality management studies" and "receiving training on quality" were compared, it was found that the difference between the groups was statistically significant $(p<0.05)$.

\section{Discussion}

Research shows that patient safety and job satisfaction were found to affect each other ${ }^{15-17}$. However, no studies have been conducted so far on the issue in Turkey. Also, this is the most comprehensive study dealing with a large number of independent variables on national and international PSCS and JSSN issues.
The participants' total PSCS mean score was 2.78 $(S D=0.47)$, suggesting the presence of positive patient safety culture. According to Türkmen et al. ${ }^{13}$, a PSCS score above two indicates the presence of positive patient safety culture. Research shows that mean PSCS scores range from one to four, and therefore, some studies report higher PSCS scores ${ }^{18-20}$, while others report lower scores ${ }^{21,22}$ than those of the participants in this study.

In a study conducted at two private hospitals in Istanbul, Turkey, which apply the Quality Standards in Health of the Turkish Ministry of Health ${ }^{18}$, reported a mean PSCS score of $3.00(S D=0.53)$, which is higher than that of the participants in this study. The hospitals in TRA2 in northeastern Turkey, where this study was conducted, lack some quality standards. Furthermore, have high labor turnover due to their location and geographical characteristics, which might explain the difference between the results of this study and those of Karaca and Arslan's study. On the other hand, Rizalar et al. ${ }^{22}$ reported a mean PSCS score of $2.64(S D=0.43)$, which is lower than that of the participants. In this study, more than $70 \%$ of the participants have received training on patient safety culture before, whereas it was about $50 \%$ in $^{22}$ study, which might account for the difference.

Moreover, in this study, the lowest PSCS subscale scores were found in "unexpected events and error reporting" and "care environment" $(2.75 ; S D=0.57)$ while the highest were found in "employee behavior" (2.82; $S D=0.53)$ and "employee training" $(2.82 ; S D=0.60)$. Karaca and Arslan ${ }^{18}$, Ertürk et al. ${ }^{19}$, Rizalar et al. ${ }^{22}$ and Yolcu et al. ${ }^{21}$ reported similar results. The nurses' PSCS subscale scores for "unexpected events and error reporting" was the lowest in the studies of Karaca and Arslan ${ }^{18}$ and Ertürk et al. ${ }^{19}$, while their PSCS subscale scores for "unexpected events and error reporting" and "care environment" were the lowest in Rizalar et al. ${ }^{22}$. Karaca and Arslan ${ }^{18}$ and Ertürk et al. ${ }^{19}$ reported the highest scores in the PSCS subscale "employee training" while Rizalar et al. ${ }^{22}$ reported the highest score in the PSCS subscale "employee behavior", which is similar to this study's results. In Yolcu et al. ${ }^{21}$, the nurses' PSCS subscale scores for "care and technology" and "employee behavior" were the lowest and the highest, respectively. Gündoğdu and Bahçecik ${ }^{23}$ found that approximately $70 \%$ of nurses did not report any errors in their units in the last year. This indicates that managers of health institutions should encourage their staff 
Table 2. Distribution of participants' PSCS and JSSN scores depending on their demographic and job-related characteristics

\begin{tabular}{|c|c|c|c|c|c|}
\hline \multirow[b]{2}{*}{ Characteristics } & \multirow[b]{2}{*}{$\mathrm{n}(\%)$} & \multicolumn{2}{|c|}{ PSCS } & \multicolumn{2}{|c|}{ JSSN } \\
\hline & & Median (S. E. *) & $\mathrm{p}^{\star *}$ & $\begin{array}{l}\text { Median/Mean } \\
\text { (S.E.*) }\end{array}$ & $\mathrm{p}^{\star *}$ \\
\hline \multicolumn{6}{|l|}{ Gender } \\
\hline Woman & $231(88.8)$ & $2.80(0.031)$ & 0.880 & $3.33(0.045)$ & 0.525 \\
\hline Man & $29(11.2)$ & $2.80(0.092)$ & $Z=-0.151$ & $3.42(0.131)$ & $t=-0.637$ \\
\hline \multicolumn{6}{|l|}{ Marital status } \\
\hline Married & $135(51.9)$ & $2.82(0.040)$ & 0.348 & $3.40(0.056)$ & 0.174 \\
\hline Single & $125(48.1)$ & $2.78(0.043)$ & $Z=-0.938$ & $3.28(0.064)$ & $\mathrm{t}=1.363$ \\
\hline \multicolumn{6}{|l|}{ Degree } \\
\hline Vocational school of health & $50(19.2)$ & $2.75(0.064)$ & 0.777 & $3.24(0.084)$ & 0.343 \\
\hline Associate & $72(27.7)$ & $2.80(0.047)$ & $K W=1.098$ & $3.40(0.079)$ & $\mathrm{F}=1.115$ \\
\hline Bachelor's & $123(47.3)$ & $2.80(0.046)$ & & $3.32(0.066)$ & \\
\hline Master's & $15(5.8)$ & $2.84(0.142)$ & & $3.57(0.152)$ & \\
\hline \multicolumn{6}{|l|}{ Spending enough time with family } \\
\hline Yes & $73(28.1)$ & $2.92(0.056)$ & 0.002 & $3.68(0.069)$ & 0.000 \\
\hline No & $187(71.9)$ & $2.76(0.034)$ & $Z=-3.058$ & $3.21(0.049)$ & $t=5.280$ \\
\hline \multicolumn{6}{|l|}{ Self-reported personality type } \\
\hline Type A (ambitious, impatient, etc.) & $149(57.3)$ & $2.76(0.039)$ & 0.035 & $3.27(0.059)$ & 0.045 \\
\hline Type B (relaxed, patient, etc.) & $111(42.7)$ & $2.84(0.043)$ & $Z=-2.114$ & $3.44(0.059)$ & $t=-2.014$ \\
\hline \multicolumn{6}{|l|}{ Choosing to be a nurse } \\
\hline Willingly & $170(65.4)$ & $2.82(0.033)$ & 0.008 & $3.46(0.051)$ & 0.000 \\
\hline Unwillingly & $90(34.6)$ & $2.67(0.055)$ & $Z=-2.637$ & $3.12(0.071)$ & $\mathrm{t}=3.904$ \\
\hline \multicolumn{6}{|l|}{ Departmental position } \\
\hline Nurse & $212(81.5)$ & $2.78(0.032)$ & 0.011 & $3.29(0.047)$ & 0.014 \\
\hline Head nurse & $38(14.6)$ & $2.85(0.074)$ & $K W=9.003$ & $3.55(0.113)$ & $\mathrm{KW}=8.538$ \\
\hline Supervisor Nurse/Assistant nursing service manager/Others & $10(3.9)$ & $3.21(0.112)$ & & $3.67(0.179)$ & \\
\hline \multicolumn{6}{|l|}{ Staff position } \\
\hline Permanent & $174(66.9)$ & $2.78(0.036)$ & 0.295 & $3.33(0.053)$ & 0.737 \\
\hline Contracted & $86(33.1)$ & $2.82(0.050)$ & $Z=-1.047$ & $3.36(0.071)$ & $t=-0.336$ \\
\hline \multicolumn{6}{|l|}{ Unit of service } \\
\hline Clinic/Service & $147(56.5)$ & $2.80(0.040)$ & 0.349 & $3.33(0.060)$ & 0.415 \\
\hline Intensive care/Emergency/0perating room & $71(27.3)$ & $2.76(0.046)$ & $\mathrm{KW}=4.447$ & $3.36(0.061)$ & $\mathrm{F}=0.987$ \\
\hline Management/Admin. & $5(1.9)$ & $3.14(0.107)$ & & $3.45(0.224)$ & \\
\hline Polyclinic & $10(3.9)$ & $2.76(0.210)$ & & $2.97(0.190)$ & \\
\hline 0thers & $27(10.4)$ & $2.78(0.109)$ & & $3.45(0.161)$ & \\
\hline \multicolumn{6}{|l|}{ Skills-job match } \\
\hline Always & $121(46.5)$ & $2.90(0.041)$ & 0.000 & $3.52(0.060)$ & 0.000 \\
\hline Sometimes & $47(18.1)$ & $2.69(0.065)$ & $K W=26.762$ & $3.11(0.101)$ & $\mathrm{F}=6.185$ \\
\hline Never & $4(1.5)$ & $2.47(0.172)$ & & $2.51(0.411)$ & \\
\hline Often & $77(29.7)$ & $2.80(0.051)$ & & $3.29(0.073)$ & \\
\hline Rarely & $11(4.2)$ & $2.43(0.141)$ & & $2.99(0.149)$ & \\
\hline Participation in decision-making in the workplace & & & & & \\
\hline Always & 141 (54.2) & $2.86(0.039)$ & 0.006 & $3.43(0.055)$ & 0.003 \\
\hline Sometimes & $96(36.9)$ & $2.78(0.046)$ & $K W=10.345$ & $3.32(0.067)$ & $\mathrm{F}=6.124$ \\
\hline Never & $23(8.9)$ & $2.55(0.115)$ & & $2.90(0.165)$ & \\
\hline Working on weekends & & & & & \\
\hline Yes & 198 (76.2) & $2.80(0.033)$ & 0.946 & $3.31(0.048)$ & 0.229 \\
\hline No & $62(23.8)$ & $2.81(0.065)$ & $Z=-0.068$ & $3.43(0.088)$ & $\mathrm{t}=-1.205$ \\
\hline Shifts & & & & & \\
\hline Yes & $187(71.9)$ & $2.80(0.035)$ & 0.544 & $3.29(0.051)$ & 0.079 \\
\hline No & $73(28.1)$ & $2.82(0.055)$ & $Z=-0.607$ & $3.46(0.076)$ & $t=-1.762$ \\
\hline Loving the profession & & & & & \\
\hline Yes & 187 (71.9) & $2.88(0.033)$ & 0.000 & $3.50(0.046)$ & 0.000 \\
\hline No & $73(28.1)$ & $2.59(0.055)$ & $Z=-4.904$ & $2.93(0.074)$ & $t=6.461$ \\
\hline Considering quitting & & & & & \\
\hline Yes & $84(32.3)$ & $2.71(0.052)$ & 0.016 & $3.14(0.077)$ & 0.001 \\
\hline No & $176(67.7)$ & $2.83(0.035)$ & $Z=-2.412$ & $3.44(0.049)$ & $t=-3.309$ \\
\hline Re-choosing to be a nurse & & & & & \\
\hline Yes & 77 (29.6) & $2.90(0.054)$ & 0.002 & $3.66(0.068)$ & 0.000 \\
\hline No & $183(70.4)$ & $2.76(0.034)$ & $Z=-3.052$ & $3.21(0.050)$ & $t=5.114$ \\
\hline Finding the profession stressful & & & & & \\
\hline Yes & $237(91.2)$ & $2.80(0.031)$ & 0.660 & $3.35(0.044)$ & 0.314 \\
\hline No & $23(8.8)$ & $2.92(0.105)$ & $Z=-0.440$ & $3.20(0.156)$ & $t=1.010$ \\
\hline Mean age & & 28.6 & 7.36 (min: 19 , & 58) & \\
\hline
\end{tabular}


Table 3. Distribution of participants' PSCS and JSSN scores depending on their satisfaction with some working conditions

\begin{tabular}{|c|c|c|c|c|c|}
\hline \multirow[b]{2}{*}{ Satisfied with } & \multirow[b]{2}{*}{ n (\%) } & \multicolumn{2}{|c|}{ PSCS } & \multicolumn{2}{|c|}{ JSSN } \\
\hline & & Median (S. E. *) & $\mathrm{p}^{\star \star}$ & Median/Mean (S.E.*) & $p^{\star \star}$ \\
\hline \multicolumn{6}{|c|}{ Working hours and shifts } \\
\hline Yes & $125(48.1)$ & $2.88(0.041)$ & 0.002 & $3.63(0.057)$ & 0.000 \\
\hline No & $135(51.9)$ & $2.75(0.041)$ & $Z=-3.029$ & $3.19(0.054)$ & $Z=-6.165$ \\
\hline \multicolumn{6}{|c|}{ Division of tasks } \\
\hline Yes & $134(51.5)$ & $2.92(0.038)$ & 0.000 & $3.63(0.050)$ & 0.000 \\
\hline No & $126(48.5)$ & $2.71(0.041)$ & $Z=-4.949$ & $3.03(0.058)$ & $t=7.760$ \\
\hline \multicolumn{6}{|l|}{ Workload } \\
\hline Yes & $70(26.9)$ & $2.97(0.059)$ & 0.000 & $3.70(0.070)$ & 0.000 \\
\hline No & $190(73.1)$ & $2.75(0.032)$ & $Z=-4.609$ & $3.21(0.048)$ & $\mathrm{t}=5.469$ \\
\hline \multicolumn{6}{|l|}{ Work pace } \\
\hline Yes & $102(39.2)$ & $2.94(0.046)$ & 0.000 & $3.62(0.059)$ & 0.000 \\
\hline No & $158(60.8)$ & $2.73(0.036)$ & $Z=-4.029$ & $3.16(0.054)$ & $t=5.715$ \\
\hline \multicolumn{6}{|c|}{ Number of nurses } \\
\hline Yes & $49(18.8)$ & $2.96(0.071)$ & 0.002 & $3.93(0.086)$ & 0.000 \\
\hline No & $211(81.2)$ & $2.76(0.031)$ & $Z=-3.030$ & $3.30(0.045)$ & $Z=-5.079$ \\
\hline \multicolumn{6}{|c|}{ Number of physicians } \\
\hline Yes & $143(55.0)$ & $2.90(0.040)$ & 0.000 & $3.47(0.056)$ & 0.001 \\
\hline No & $117(45.0)$ & $2.75(0.041)$ & $Z=-3.750$ & $3.19(0.062)$ & $t=3.354$ \\
\hline \multicolumn{6}{|c|}{ Number of patients } \\
\hline Yes & $108(41.5)$ & $2.96(0.049)$ & 0.000 & $3.61(0.062)$ & 0.000 \\
\hline No & $152(58.5)$ & $2.74(0.034)$ & $Z=-4.344$ & $3.15(0.053)$ & $t=5.639$ \\
\hline \multicolumn{6}{|c|}{ Interpersonal relationships in the workplace } \\
\hline Yes & $187(71.9)$ & $2.84(0.036)$ & 0.003 & $3.46(0.047)$ & 0.000 \\
\hline No & $73(28.1)$ & $2.71(0.044)$ & $Z=-2.948$ & $3.03(0.081)$ & $\mathrm{t}=4.705$ \\
\hline \multicolumn{6}{|c|}{ Working for the institution } \\
\hline Yes & $137(52.7)$ & $2.96(0.039)$ & 0.000 & $3.64(0.048)$ & 0.000 \\
\hline No & $123(47.3)$ & $2.67(0.039)$ & $Z=-6.394$ & $3.00(0.059)$ & $t=8.464$ \\
\hline \multicolumn{6}{|c|}{ Working in unit/service/department } \\
\hline Yes & $197(75.8)$ & $2.86(0.035)$ & 0.000 & $3.48(0.045)$ & 0.000 \\
\hline No & $63(24.2)$ & $2.69(0.046)$ & $Z=-3.997$ & $2.89(0.084)$ & $\mathrm{t}=6.417$ \\
\hline \multicolumn{6}{|c|}{ Training on patient safety } \\
\hline Yes & $152(58.5)$ & $2.94(0.034)$ & 0.000 & $3.54(0.049)$ & 0.000 \\
\hline No & $108(41.5)$ & $2.54(0.043)$ & $Z=-7.034$ & $3.06(0.066)$ & $\mathrm{t}=6.040$ \\
\hline \multicolumn{6}{|l|}{ Income } \\
\hline Yes & $80(30.8)$ & $2.94(0.059)$ & 0.000 & $3.66(0.074)$ & 0.000 \\
\hline No & $180(69.2)$ & $2.75(0.032)$ & $Z=-3.902$ & $3.20(0.048)$ & $t=5.200$ \\
\hline
\end{tabular}

${ }^{*}$ S.E.; Standard error; ${ }^{* \star} \mathrm{p}<0.05$; PSCS; patient safety culture scale; JSSN; job satisfaction scale in nurses.

to report errors and unexpected events. Furthermore, nurses are thought not to have enough knowledge of safety precautions related to care environments.

Yilmaz and Yildirim ${ }^{14}$ state that the closer the JSSN score is to five, the higher the job satisfaction. The participants' mean JSSN score was $3.34(S D=0.68)$, indicating an above-average job satisfaction. Research shows that mean JSSN scores range from one to five, and therefore, some studies reported higher JSSN scores ${ }^{14}$, while others reported lower scores ${ }^{24,25}$ than those of the participants in this study. Yilmaz and Yildirim ${ }^{14}$ reported a mean JSSN score of 4.00 $(S D=0.56)$, which is higher than that of this study's participants. This might be due to the higher number 
of high school graduate nurses in Yilmaz and Yildirim's study ${ }^{14}$. Yang et al. ${ }^{24}$ reported a mean job satisfaction score of $2.51(S D=0.98)$, which is lower than that of the participants of this study.

In this study, the lowest JSSN subscale score was found in "pleasant working environment" $(2.67 ; S D=0.97)$ and the highest in "perceived significance in the workplace" (3.80; $S D=0.70)$. The results reported by Yilmaz and Yildirim ${ }^{14}$ are similar to this study's results. The subscale "pleasant working environment" consists of items about taking into consideration individual circumstances, balancing work and private life, having an appropriate number of personnel, receiving a sufficient salary and requests for days off. The low "pleasant working environment" subscale score, therefore, suggests that participants' expectations regarding these matters are not met. Since 2016, when the JSNN was adapted to the Turkish language and its validity and reliability were established, there have been no further studies using the scale.

There is a positive correlation between the PSCS and JSSN total scores ${ }^{26}$. Each independent variable that affects the PSCS also affects the JSSN, suggesting that there is a correlation between the two. There are no national studies, to the researchers' knowledge, that comparatively analyzes nurses' patient safety culture and job satisfaction; however, there are international studies that $\mathrm{do}^{15,16,27-30}$. They report that the higher the nurses' job satisfaction, the better the patient outcomes and the higher the patient safety. They, therefore, recommend that attempts and interventions to improve patient safety culture also take into account levels of nurses' job satisfaction.

Participants who is choses to be a nurse of their own free will, had higher departmental positions, always or often found their job appropriate to their skills and participate in decision-making in the workplace had higher PSCS and JSSN scores. Participants who were satisfied with working hours and shifts, division of tasks, workload and work pace, the number of nurses, the number of physicians and the number of patients, interpersonal relationships in the workplace, the institution they work for, the unit in which they work, and training programs provided for patient safety and income had higher PSCS and JSSN scores. Participants who love being a nurse, do not consider quitting, serve on the patient safety committee, have received training on patient safety in the institution they work for or before, consider the presence of a patient safety committee necessary, have participated in staff orientation and received training on teamwork and quality, spend enough time with their families, state that they would choose to be a nurse if they were given the chance, read the announcements on patient and staff safety, know about total quality management studies, had a high-quality education and have a Type B personality had higher PSCS and JSSN scores.

When the PSCS and JSSN scores for the independent variables stated above were compared, it was found that the difference between the groups was statistically significant $(p<0.05)$. National or international studies have investigated the effects of a limited number of variables on nurses' patient safety culture and job satisfaction. No national or international studies have ever examined all of the independent variables that caused the significant differences observed in this study; therefore, the results are discussed in a limited context.

Wami et al. ${ }^{31}$ reported that patient safety culture is correlated with weekly working hours, number of staff, teamwork, good communication, unexpected events and error reporting and participating in patient safety training, which is similar to this study's results. Ball et al. ${ }^{15}$ reported that longer working hours showed a decline in patient safety. Alqattan et al. ${ }^{32}$ reported that nurses who took training or courses regarding patient safety had significantly higher patient safety culture than those who did not. Dinçer ${ }^{33}$ found that receiving training on quality increases patient safety culture.

Tilev and Beydag ${ }^{11}$ reported that the higher the number of working hours, the lower the job satisfaction, while Çalişkan ${ }^{34}$ found that those who chose to be a nurse of their own free will have higher overall job satisfaction. Tambağ et al. ${ }^{35}$ found that nurses who are satisfied with their department have higher job satisfaction than those who are not. Lorber and Savic ${ }^{12}$ reported that head nurses who are involved in decisionmaking in the workplace and satisfied with working hours have higher job satisfaction than the ones who are not satisfied with working hours. Nurses who love their profession work more effectively and efficiently, resulting in higher job satisfaction and patient safety culture.

\section{Limitations}

The results can only be generalizable to the nurses of the hospitals where this study was conducted. 


\section{Conclusion}

There is a moderate positive relationship between nurses' patient safety culture and job satisfaction. It was concluded that nurses who have a high patient safety culture have high job satisfaction.

Patient safety culture in institutions should be systematically evaluated and interventions should be undertaken to improve it. Training programs should be organized to raise awareness of patient safety. Hospital managers should find ways to eliminate factors that reduce nurses' job satisfaction and to increase their motivation. Working environments and weekly working hours and shifts should be arranged to improve nurses' job satisfaction. Interventions should be initiated to encourage nurses to report unexpected errors and adverse events.

\section{Conflict of Interest}

There are no conflicts of interest to disclose.

\section{Acknowledgments}

We would like to thank all nurses who took the time to participate in this study.

\section{Author Contributions}

Study design: KO, AKA

Data collection: KO, AKA

Data analysis: KO, AKA

Manuscript writing: KO, AKA

Critical Review, and/or Revision: AKA

"This study was orally presented at the 1 st International Congress on Innovative Appproaches in Nursing in Turkey."

“This study was prepared from Kader Cifci' master thesis under the supervision of Assistant Professor Arzu Karabag Aydin."

\section{References}

1. WHO-2018a. World Health Organization (WHO), Patient Safety. Retrieved from http://www.euro.who.int/en/healthtopics/Health-systems/patient-safety/patient-safety

2. Kohn LT, Corrigan JM, Donaldsan MS. Institute of Medicine (IOM). To Err Is Human: Building a safer health system. Washington DC: Institute of medicine, National academy press; 1999. p.1-34.
3. WHO-2018b World Health Organization (WHO), Patient Safety. Retrieved from https://www.who.int/news-room/factsin-pictures/detail/patient-safety

4. Baker R, Norton P, Flintoff V, Blais R, Brown A, Cox J, et al. The canadian adverse events study: the incidence of adverse events among hospital patients in Canada. CMAJ 2004;170(11):1678-1686.

5. WHO-2018c World Health Organization (WHO), Patient Safety. Retrieved from https://www.who.int/patientsafety/ en/

6. International Council of Nurses (ICN) [International Council of Nurses web site] Available at: https://www.icn.ch/sites/ default/files/inline-files/D05_Patient_Safety.pdf Accessed January 9, 2018. Position Statement: Patient Safety, Geneva, Switzerland. (2012):1-3.

7. Dharitri S. Job satisfaction of nursing staff and patients' perception of quality care in a tertiary teaching hospital. Odisha. Asian Journal Nursing Education and Research 2016;6(3):2231-1149.

8. Durmuş $S$, Günay $O$. Factors affecting job satisfaction and anxiety levels in the nurses. Erciyes Medical Journal 2007;29(2):139-146.

9. Park M, Lee JY, Cho S. Newly graduated nurses' job satisfaction: comparison with allied hospital professionals, social workers, and elementary school teachers. Asian Nursing Research 2012;6(3):85-90.

10. Çalışkan S. Hemşirelerde İş Doyumu ve Bunu Etkileyen Faktörlerin Belirlenmesi [Job satisfaction in nurses and determination of factors affecting it]. Türk Hava Kurumu Üniversitesi, Sosyal Bilimler Enstitüsü, Yüksek Lisans Tezi, Ankara, Turkey; 2014.

11. Tilev S, Beydağ KD. Hemşirelerin iş doyumu düzeyi. [Job satisfaction level of nurses]. Journal of Health and Nursing Management 2014;1(3):140-146.

12. Lorber M, Savic BS. Job satisfaction of nurses and identifying factors of job satisfaction in slovenian hospitals. Croatian Medical Journal 2012;53(3):263-70.

13. Türkmen E, Baykal Ü, Seren Ş, Altuntaş S. Hasta güvenliği kültürü ölçeğinin geliştirilmesi. [Development of patient safety culture scale]. Anadolu Hemşirelik ve Sağlık Bilimleri Dergisi 2011;14(4):38-46.

14. Yılmaz AT, Yıldırım A. Hemşire iş doyum ölçeğinin Türkçe geçerlilik ve güvenirliği, [Validity and reliability of the nurse job satisfaction scale in Turkish]. Journal of Health and Nursing Management 2016;3(3):158-168.

15. Ball J, Day T, Murrels T, Dall'Ora C, Rafferty AM, Griffiths P, Maben J. Cross-sectional examination of the association between shift length and hospital nurses job satisfaction and nurse reported quality measures. Biomed Central Nursing 2017:16-26.

16. Inoue T, Karima R, Harada K. Bilateral effects of hospital patient-safety procedures on nurses' job satisfaction. International Nursing Review 2017;64(3):437-445. 
17. Boamah SA, Read EA, Laschinger HK. Factors influencing new graduate nurse burnout development, job satisfaction and patient care quality: A time-lagged study. Journal of Advanced Nursing, (2016);73(5):1182-1195. doi: 10.1111/ jan 13215

18. Karaca A, Arslan H. Hemşirelik hizmetlerinde hasta güvenliği kültürünün değerlendirilmesine yönelik bir çalı̧̧ma. [A study for evaluation of patient safety culture in nursing services]. Sağlık ve Hemşirelik Yönetimi Dergisi 2014;1(1):9-18.

19. Ertürk C, Dönmez P, Özmen D. Manisa il merkezindeki hastanelerde görev yapan hemşirelerin hasta güvenliği kültürünün değerlendirilmesi. [Evaluation of Patient Safety Culture of Nurses Working in Hospitals in Manisa Province Center]. Ege Üniversitesi Hemşirelik Fakültesi Dergisi 2016;32(1):19-33.

20. Mohr CD, Lipkowitz Eaton J, Kathleen M, Hodgson MJ. Does employee safety matter for patients too? Employee safety climate and patient safety culture in health care. Journal of Patient Safety 2018;14(3):181-185.

21. Yolcu N, Yıldırım Z, İncesu E, Yiğit Y, Çağ Y. Tekirdağ ili kamu hastanelerinde çalışan hemşireler için hasta güvenliği kültürünün değerlendirilmesi. [Evaluation of the patient safety culture of the public hospitals in the Tekirdağ: Survey of Nurses]. International Anatolia Academic Online Journal Scientific Science 2015;3(2):8-18.

22. Rızalar S, Tural Büyük E, Şahin R, As T, Uzunkaya G. Hemşirelerde hasta güvenliği kültürü ve etkileyen faktörler. [Patient safety culture in nurses and affecting factors] Dokuz Eylül Üniversitesi Hemşirelik Fakültesi Elektronik Dergisi 2016;9(1):9-15.

23. Gündoğdu S, Bahçecik N. Hemşirelerde hasta güvenliği kültürü algilamasının belirlenmesi [Determination of patient safety culture perception in nurses] Anadolu Hemşirelik ve Sağlık Bilimleri Dergisi 2012;15(2):119-128.

24. YangJ,Liu Y,Chen Y,PanX.Theeffect of structuralempowerment and organizational commitment on chinese nurses' job satisfaction. Applied Nursing Research. (2014);27(3):186-191. https://doi.org/10.1016/j.apnr.2013.12.001

25. Higgins EA. The influence of nurse manager transformational leadership on nurse and patient outcomes: Mediating effects of supportive practice environments, organizational citizenship behaviours, patient safety culture and nurse job satisfaction. Electronic Thesis and Dissertation Repository. (2015):3184.
26. Spence, Laschinger HK, Fida R. Linking nurses' perceptions of patient care quality to job satisfaction. The Journal of Nursing Administration 2015;45(5):276-283.

27. Chiang HY, Hsiao YC, Lee HF. Predictors of hospital nurses' safety practices work environment, workload, job satisfaction, and error reporting. Journal of Nursing Care Quality 2017;32(4): 359-368. doi: 10.1097/NCQ.0000000000000240

28. Bondevik TG, Hofoss D, Husebo SB, Deilkas EC. Patient safety culture in norwegian nursing homes. Biomed Central Health Services Research 2017;17:424.

29. Tondo JCA, Guirardello EB. Perception of nursing professionals on patient safety culture. Rev Bras Enferm 2017;70(6):128490. http://dx.doi.org/10.1590/0034-7167-2016-0010

30. Boamah SA, Spence Laschinger HK, Wong C, Clarke S. Effect of transformational leadership on job satisfaction and patient safety outcomes. Nursing Outlook 2018;66(2):180-189. doi: 10.1016/j.outlook.2017.10.004

31. Wami SD, Demssie AF, Wassie MM, Ahmed AN. Patient safety culture and associated factors: A quantitative and qualitative study of healthcare workers' view in jimma zone hospitals, southwest ethiopia. Biomed Central Health Services Research. (2016);16:495, 1-10.

32. Alqattan H, Cleland J, Morrison Z. An evaluation of patient safety culture in a secondary care setting in Kuwait. Journal of Taibah University Medical Sciences. (2018);13(3):1-9.

33. Dinçer $M$, Torun N, Aksakal H. Determining nurses' perceptions of patient safety culture in palliative care centres. Contemporary Nurse. (2018);54(3):246-257.

34. Çalışkan, A., Yeni Mezun Hemşirelerde İş Doyumu Tükenmişlik ve Gerçeklik Şokunun İncelenmesi. [Investigation of job satisfaction burnout and reality shock in newly graduated nurses]. Marmara Üniversitesi, Sağlık Bilimleri Enstitüsü, Yüksek Lisans Tezi, İstanbul, Turkey, (2010).

35. Tambağ H, Can R, Kahraman Y, Şahpolat M. Hemşirelerin çalışma ortamlarının iş doyumu üzerine etkisi, [The effect of nurses' work environments on job satisfaction]. Medical Journal of Bakırköy, (2015);11(4):143-149. 